\title{
Phosphorus retention in streams draining pine and hardwood catchments in the southern Appalachian Mountains
}

\author{
D.J. D'ANGELO* and J.R. WEBSTER Department of Biology, Virginia Polytechnic \\ Institute and State University, Blacksburg, Virginia, U.S.A.
}

SUMMARY. 1. This study was designed to determine how catchment use affects stream phosphorus retention by comparing retention in streams draining three mixed hardwood catchments and three catchments that were planted in white pine in the $1950 \mathrm{~s}$.

2. Catchments of similar area and stream discharge were chosen and phosphorus uptake was measured monthly in each catchment along with temperature, discharge, velocity, coarse particulate organic matter (CPOM), fine particulate organic matter (FPOM), and microbial respiration associated with FPOM.

3. On an annual basis, average phosphorus retention was not different between streams draining pine and hardwood catchments nor were there significant differences between physical (temperature, velocity and discharge) or biological (CPOM, FPOM and respiration) parameters based on catchment type. However, discharge was more variable in streams draining pine catchments.

4. Because phosphorus uptake was correlated with discharge, phosphorus retention was also more variable in streams draining pine catchments. Storms caused a greater increase in discharge and loss of phosphorus in pine streams than in mixed hardwood streams, but discharge returned to baseline more quickly in pine streams.

5. We suggest that discharge regimes and phosphorus dynamics of streams draining pine catchments are less resistant to change but more resilient than streams draining mixed hardwood forests.

\section{Introduction}

Small catchments provide a convenient means of examining whole-ecosystem phenomena (Monk et al., 1977). At Coweeta Hydrologic Laboratory and other sites, nutrient studies of

* Present address: Department of Fisheries and Wildlife, Oregon State University, Corvallis, Oregon 97331, U.S.A. small catchments have been used to assess the consequences of land-use practices (Odum, 1969; Bormann et al., 1974; Monk et al., 1977) because they provide an integrative measure of ecosystem responses to disturbance (Monk et al., 1977; Van Voris et al., 1980; Minshall et al., 1983). It has been suggested that disturbed ecosystems are less efficient at retaining nutrients than undisturbed or mature ecosystems (Odum, 1969; Fisher \& Likens, 1973; Bormann 
et al., 1974; Vitousek \& Reiners, 1975). Because land disturbances ultimately affect stream ecosystems, stream nutrient studies are an important part of land-use assessment. In streams, spiralling length, which incorporates nutrient cycling and downstream transport, provides a measure of retention (Newbold et al., 1982). In this study, a component of nutrient spiralling length, uptake length, was used to measure differences in phosphorus retention capabilities of streams draining hardwood and white-pine catchments.

Much of the forested land in the south-eastern United States is dominated by pine trees. In addition, many mixed forests and other land types are being logged and turned into pine plantations. Because pine trees intercept and transpire more water than hardwoods (Helvey, 1967; Swank \& Douglass, 1974), conversion of lands from mixed hardwood forests to pine forests results in decreased water yields (Swank \& Miner, 1968), which is expressed as lower stream discharge and water velocity. Furthermore, annual litterfall is lower in pine catchments than in hardwood catchments (Cromack \& Monk, 1975) and is comprised predominantly of wood and pine needles, which breakdown slowly in streams and do not support high levels of microbial biomass or respiration (Triska, Sedell \& Gregory, 1982).

Previous work on phosphorus retention in streams has revealed that retention is strongly influenced by factors such as stream velocity and the biomass and quality of coarse particulate organic matter (CPOM) and fine particulate organic matter (FPOM). Various researchers have shown that phosphorus uptake is negatively correlated with stream velocity (Meyer, 1979; Newbold et al., 1983; Mulholland et al., $1985)$ and positively correlated with organic matter biomass (Newbold et al., 1983). Uptake and sorption of phosphorus on to organic matter is primarily due to biotic mechanisms such as incorporation by microbes (Gregory, 1978; Elwood et al., 1981). A study by D'Angelo (1990) showed that CPOM quality influenced phosphorus uptake.

This study was designed to examine effects of physical (e.g. discharge and velocity) and biological (e.g. organic matter biomass and composition) characteristics of streams draining white-pine and mixed hardwood catchments on phosphorus retention to determine whether the two catchment types had different phosphorus retention capabilities and if so, what factors were important in regulating retention.

\section{Methods}

\section{Description of catchments}

Catchments used in this study were located at Coweeta Hydrologic Laboratory, a 2270-ha experimental forest in the southern Appalachian Mountains of western North Carolina, U.S.A. The temperature in this region is moderate with an annual mean of $13^{\circ} \mathrm{C}$ and average annual rainfall of about $2 \mathrm{~m}$ (Swift, Cunningham \& Douglass, 1988). Catchments at Coweeta are designated as either experimental or reference. Reference catchments have not been disturbed since 1900-1924 when the entire area was selectively logged. For this study, three reference catchments $(2,14$ and 18) were chosen along with three experimental catchments $(1,3$ and 17) that had been cut and planted in white pine (Pinus strobus). Catchment 1 was cut in 195657 and planted in white pine in 1957. Catchment 3 was used for agriculture between 1940 and 1952 and then planted in white pine with some yellow poplar in the upper reaches. Catchment 17 was cut in 1942 , regrowth was recut annually between 1942 and 1955 and the catchment was planted in white pine in 1956 (Swank \& Crossley, 1988). Basin sides and stream banks were unstable in the pine catchments, perhaps as a result of loss of surface soil following cutting, or to the lack of understory vegetation. Pine and hardwood catchments had approximately the same area, slope and stream discharge. Catchments were chosen from the north-east and south-west sides of the basin to obtain catchments of similar elevation. Their physical characteristics are summarized in Table 1.

\section{Phosphorus uptake}

Phosphorus uptake experiments were conducted in the streams at monthly intervals from October 1988 to September 1989 to determine phosphorus retention. A $20-30-\mathrm{m}$ reach of stream was chosen near the bottom of each catchment, just above the weir. One of the hardwood streams drained a sub-catchment of a larger catchment (14) however, and the study reach was at the downstream-most end of the 
TABLE 1. Physical characteristics of streams and catchments used in this study*

\begin{tabular}{|c|c|c|c|c|c|c|}
\hline \multirow{2}{*}{ Catchment } & \multicolumn{2}{|l|}{ Pine } & \multicolumn{4}{|c|}{ Hardwood } \\
\hline & 1 & 3 & 17 & 2 & $14^{\dagger}$ & 18 \\
\hline Aspect & SE & SE & NW & SE & NW & NW \\
\hline Area (ha) & 16 & 9 & 13 & 12 & $14^{\ddagger}$ & 13 \\
\hline \multicolumn{7}{|l|}{ Catchment elevation (m) } \\
\hline Maximum & 988 & 931 & 1021 & 1004 & 992 & 993 \\
\hline Minimum & 755 & 739 & 760 & 709 & 707 & 726 \\
\hline \multicolumn{7}{|l|}{$\begin{array}{l}\text { Stream slope in } \\
1988-89 \text { discharge }\left(1 \mathrm{~s}^{-1}\right)\end{array}$} \\
\hline study area $\left(\mathrm{cm} \mathrm{m}^{-1}\right)$ & 16 & 14 & 20 & 18 & 13 & 23 \\
\hline Mean annual & 1.91 & $1.30^{\S}$ & 2.38 & 2.65 & $2.80^{\S}$ & 2.35 \\
\hline Maximum & 4.27 & - & 5.84 & 5.22 & - & 4.41 \\
\hline Minimum & 0.52 & - & 0.29 & 0.44 & - & 0.43 \\
\hline Mean SRP $\left(\mu g 1^{-1}\right)$ & $<2.0$ & $<2.0$ & $<2.0$ & $<2.0$ & $<2.0$ & $<2.0$ \\
\hline
\end{tabular}

* Data from this study and Swank \& Crossley (1988).

${ }^{+}$We used a sub-basin of the 60-ha catchment 14 .

₹ Estimated from topographical map.

${ }^{8}$ Estimated from ratio of area to discharge of similar catchment type.

non-gauged sub-catchment. A solution containing phosphate (as $\mathrm{Na}_{2} \mathrm{HPO}_{4}$ ) and chloride (as $\mathrm{NaCl}$ ) was released into each stream for a time sufficient to allow concentrations to plateau $(30-50 \mathrm{~min}$ based on previous experiments). Release concentrations were $5-10 \mathrm{x}$ ambient levels (about $30 \mu \mathrm{gl}^{-1}$ soluble reactive phosphate, SRP, and $3 \mathrm{mg} \mathrm{l}^{-1} \mathrm{Cl}^{-}$). Chloride (as $\mathrm{NaCl}$ ) is conservative in most streams and was used to account for dilution and dispersal (Bencala, McKnight \& Zellweger, 1987).

At the downstream end of the reach, water samples were taken every 5-10 $\mathrm{min}$ from the onset of the release until the concentration had reached its plateau, at which time water samples were taken at five stations ( $5 \mathrm{~m}$ apart) along the stream. Solution input was then stopped and sample collection continued at the downstream end of the reach at 5-10 min intervals for an additional $30 \mathrm{~min}$. Samples were filtered as they were collected $(0.45-\mu \mathrm{m}$ Gelman A/E glass fibre filters), taken to the laboratory, and refrigerated $\left(4^{\circ} \mathrm{C}\right)$. They were analysed within $24 \mathrm{~h}$ for SRP and chloride or frozen for not more than 3 months and analysed within $24 \mathrm{~h}$ of thawing.

All chemical analyses of water samples were performed at Coweeta Hydrologic Laboratory using protocols described by Reynolds \& Deal (1986). Phosphorus and chloride were analysed with a three-channel Technicon AutoanalyserII system. SRP concentrations were measured using the ammonium-molybdate reaction.
Chloride was determined by the ferricyanide method.

Fig. 1 is an example of the chloride curve produced from water samples collected at the downstream station. These data were used to calculate stream velocity by integrating the area under the curve and determining the time for half of the chloride to pass the downstream station. The difference between the time at

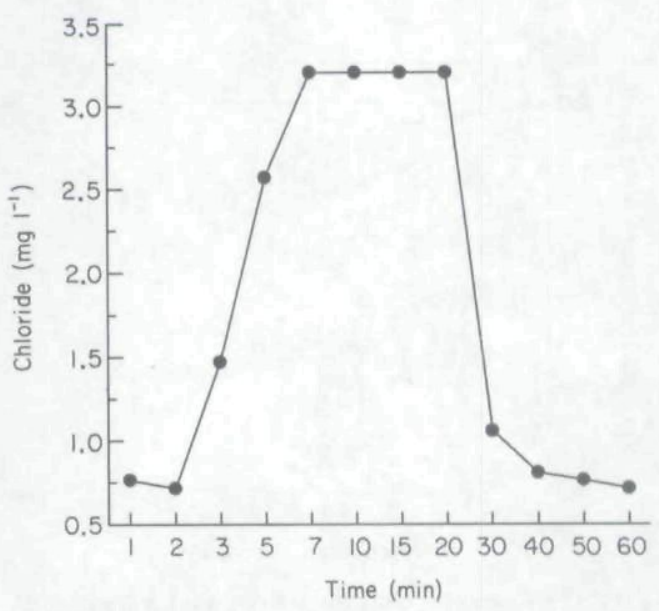

FIG. 1. Example chloride curve produced from samples collected at the downstream site. Mean stream velocity was determined by calculating the area under the curve and determining the travel time for half of the chloride relative to the time when half of the chloride had been released. 
which half of the solution was released and the time for half of the chloride to pass the station was taken to be the nominal transport time (Triska et al., 1989). Velocity equals distance divided by nominal transport time. For uptake experiments without a chloride curve, velocity was determined by releasing rhodomine dye into the stream and measuring travel time. Because velocity determined with rhodomine dye is maximum velocity, a regression equation relating nominal transport time and maximum velocity was used to convert maximum velocities obtained from rhodomine dye releases to average velocities comparable to the nominal transport time obtained from chloride data.

The downstream decline in chloride concentration (Fig. 2) was used to correct phosphorus concentration for dilution and dispersion. After correction, phosphorus data were expressed as per cent upstream concentration, and uptake
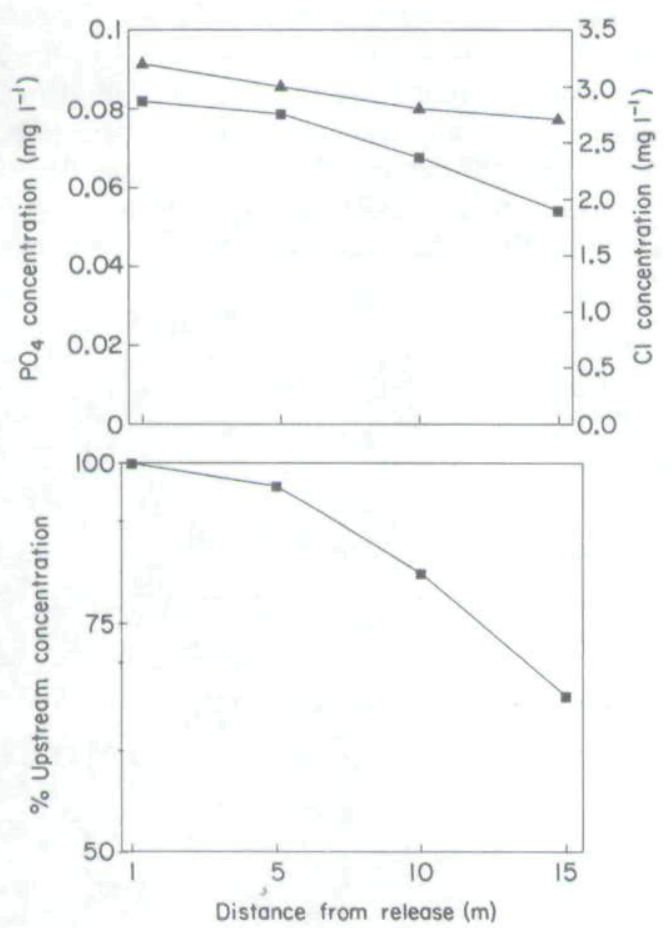

FIG. 2. Example chloride curve and phosphorus curve produced from samples collected at sites along the length of the stream. (a) Downstream decline in phosphorus ( $\mathbf{m})$ and chloride ( $\mathbf{\Delta}$ ) concentrations. (b) Phosphorus concentration corrected for losses resulting from dilution and dispersion and expressed as a per cent of upstream concentration. $\left(\mathrm{m}^{-1}\right)$ was calculated as the slope of the line relating the natural logarithm of concentration to distance (Fig. 2). The inverse of the uptake rate yields uptake length, i.e. the average distance that a nutrient ion travels before being sorbed on to particulates or taken up by the biota (Newbold et al., 1981). Uptake rate $\left(\mathrm{s}^{-1}\right)$ was calculated by multiplying uptake per unit length $\left(\mathrm{m}^{-1}\right)$ by velocity $\left(\mathrm{m} \mathrm{s}^{-1}\right)$.

\section{Benthic samples}

CPOM and FPOM samples were taken monthly from three randomly chosen sites (one core per site) in each stream. Samples were taken with a metal corer $\left(0.071 \mathrm{~m}^{2}\right)$, which was pushed into the sediment. CPOM was removed from the core, placed in a plastic bag and later dried and sorted to determine dry weight of leaves and sticks. Sediments in the core were repeatedly stirred to a depth of $10 \mathrm{~cm}$ and sucked with a suction pump through a $250-\mu \mathrm{m}$ mesh net into a bucket. The volume of water in the bucket was recorded and a $125-\mathrm{ml}$ aliquot of the FPOM/water slurry was removed from the bucket for filtration. Filtered material was then dried, weighed and ashed, to determine total FPOM ash free dry mass (AFDM) $\mathrm{m}^{-2}$. Material in the net $(>250 \mu \mathrm{m})$ was included with the CPOM.

Microbial activity on the FPOM was determined by measuring ${ }^{14} \mathrm{C}$ glucose respiration. Aliquots $(5 \mathrm{ml})$ of an FPOM slurry were pipetted into incubation flasks. Labelled ${ }^{14} \mathrm{C}$ glucose (specific activity $304.7 \mathrm{mCi} \mathrm{mmol}^{-1}$ ) was added to the slurry to obtain a concentration of $0.5 \mu \mathrm{g}$ glucose $1^{-1}$ and the flask was sealed with a rubber septum. Filter paper suspended in the flask above the slurry was soaked with phenethylamine to capture the ${ }^{14} \mathrm{C}$ respired (Mulholland et al., 1985). The slurry was incubated for $3 \mathrm{~h}$ based on a preliminary study in which an incubation curve was run to determine the maximum incubation time that minimized isotopic dilution (King \& Berman, 1984). At the end of the incubation period, respiration was stopped by adding $0.2 \mathrm{ml}$ of $6 \mathrm{~N} \mathrm{H}_{2} \mathrm{SO}_{4}$ and the filter paper was removed from the flask and placed in scintillation cocktail for counting on a Beckman scintillation counter. Another 5 -ml aliquot of the original slurry was collected on a pre-ashed $0.45-\mu \mathrm{m}$ Gelman filter, dried, weighed and ashed to determine AFDM. 


\section{Results}

\section{Physical parameters}

No significant differences in stream temperature were found between hardwood and pine streams. Mean water temperature in October was $10^{\circ} \mathrm{C}$, dropped to a low of $6^{\circ} \mathrm{C}$ in January, and rose to a maximum temperature of $16^{\circ} \mathrm{C}$ in July (Fig. 3).

Discharge data for two of the pine catchments and two of the hardwood catchments were obtained from the weirs continuously and at the time of the uptake experiments (Fig. 4). Lowest discharges occurred in autumn $\left(0.51 \mathrm{~s}^{-1}\right)$. Discharge increased to about $3.71 \mathrm{~s}^{-1}$ during February and dropped to about half that level in spring. Discharges of over $4.01 \mathrm{~s}^{-1}$ occurred on June and July uptake experiment dates because of a series of storms. Discharge then dropped to about $2.01 \mathrm{~s}^{-1}$ (Fig. 4) by late summer. Discharge data collected on days of the uptake experiments were used for statistical analyses.

Although annual patterns were similar for the two catchment types, discharge in the pine catchments was significantly lower (ANOVA, $P<0.05)$ and more variable $\left(\right.$ mean $=2.141 \mathrm{~s}^{-1}$, coefficient of variation $=89 \%$ ) than in the hardwood catchments (mean $=2.501 \mathrm{~s}^{-1}$, coefficient of variation $=53 \%$; Fig. 4). Discharge in the pine streams increased to a greater extent in response to storms than in the hardwood streams and dropped to lower levels during the drier periods (i.e. January-May). Furthermore, when the impact of storms on streamflow was compared in adjacent pine and hardwood catchments, data showed that in streams draining the former, storms produced higher ratios of peak flows to baseflow, a higher ratio of quickflow to delayed flow and shorter periods of elevated flow (paired $t$-test, $P<0.05$; Table 2). In other words, in streams draining pine catchments, flow was increased to a greater extent but for a shorter period of time than in adjacent hardwood streams. Velocity exhibited a pattern similar to discharge and was significantly correlated with discharge $(R=0.806, P<0.0001$, $n=48$ ) (Fig. 5), but no significant difference in velocity was found between the two catchment types (ANOVA, $P>0.05$ ).

Despite attempts to choose catchments with similar physical characteristics, there were differences in stream temperature and catch- ment slope. Catchments on the NW side of the Coweeta basin were significantly colder (10.1 and $11.5^{\circ} \mathrm{C}$, respectively) and steeper (average slope 18.5 and $16.4 \mathrm{~cm} \mathrm{~m}^{-1}$, respectively) than catchments on the SE side (ANOVA, $P<0.05$ ). As a result of slope differences, streams on the
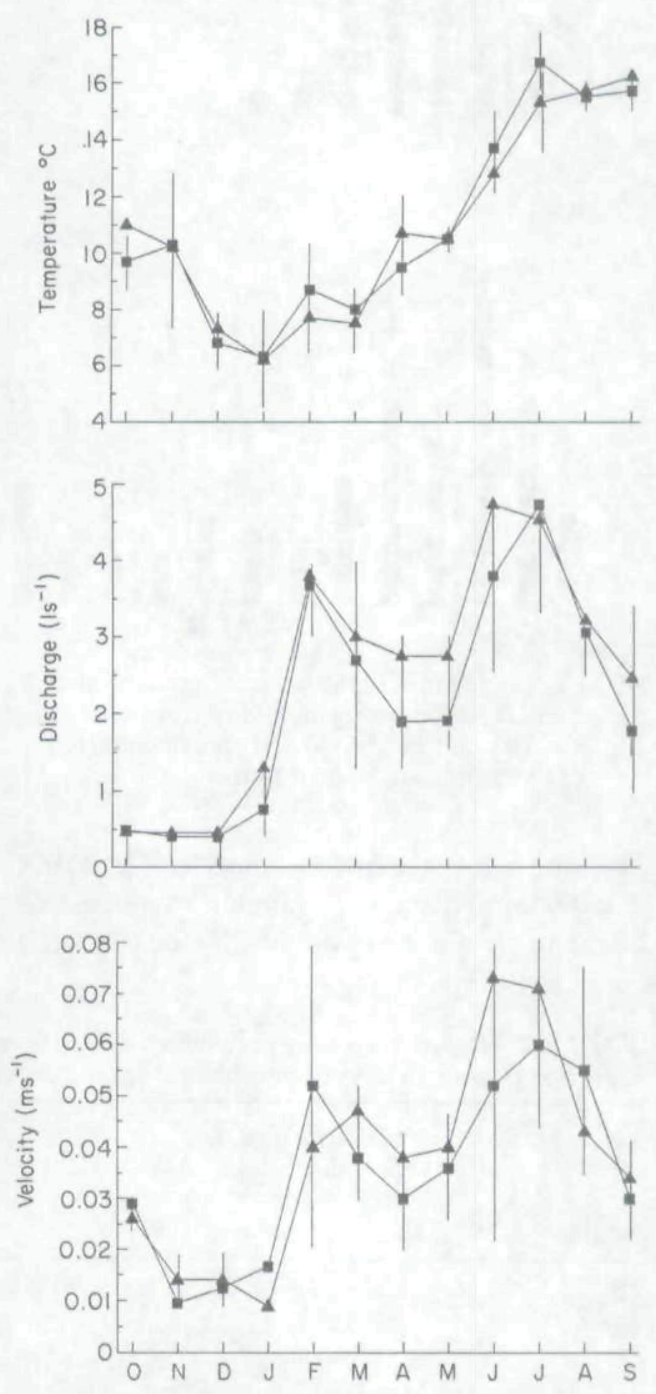

FIG. 3. (a) Mean temperature $\left({ }^{\circ} \mathrm{C}\right)$, (b) mean discharge $\left(1 \mathrm{~s}^{-1}\right)$ and (c) mean velocity $\left(\mathrm{m} \mathrm{s}^{-1}\right)$ in the streams draining pine (E) and hardwood (A) catchments. Temperature and velocity are shown for all six streams, but discharge is shown for only two of the pine $(1,17)$ and two of the hardwood catchments $(2,18)$. Discharge data were not available for the other two catchments. All data were collected at the time of the monthly phosphorus uptake experiments. Vertical bars indicate standard error. 

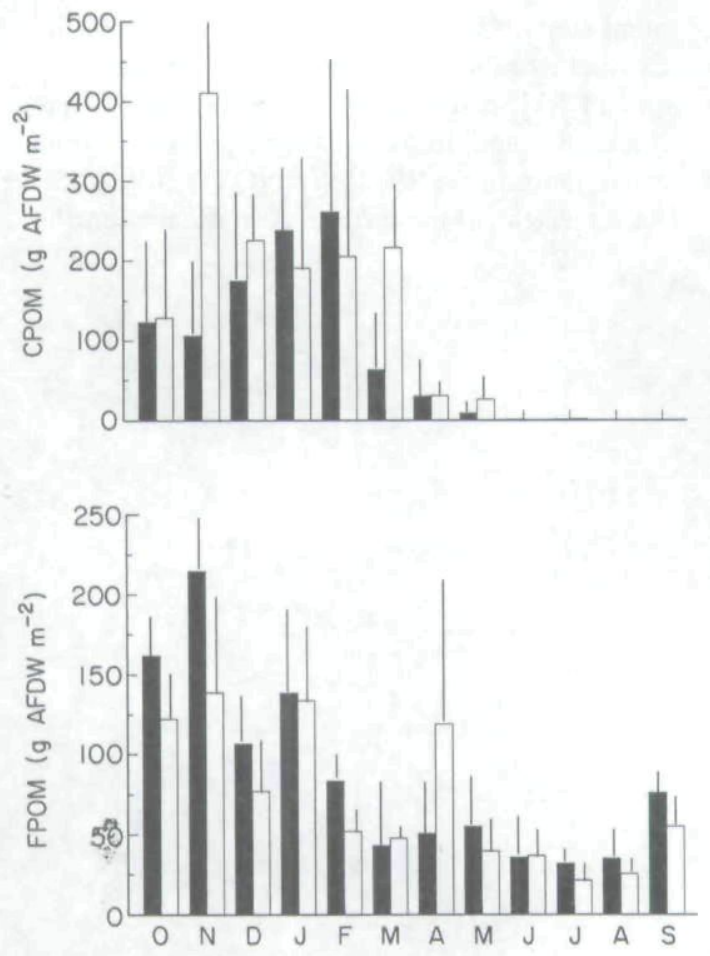

FIG. 4. (a) Mean CPOM biomass $\left(\mathrm{g} \mathrm{m}^{-2}\right)$ and (b) mean FPOM biomass $\left(\mathrm{g} \mathrm{m}^{-2}\right)$ in streams draining the pine (घ) and hardwood ( $\square)$ catchments $(n=3)$. Vertical bars indicate standard error.

NW side had faster current velocities (ANOVA, $P<0.009)$ and smaller Manning roughness coefficients than streams on the SE side (Table 3).

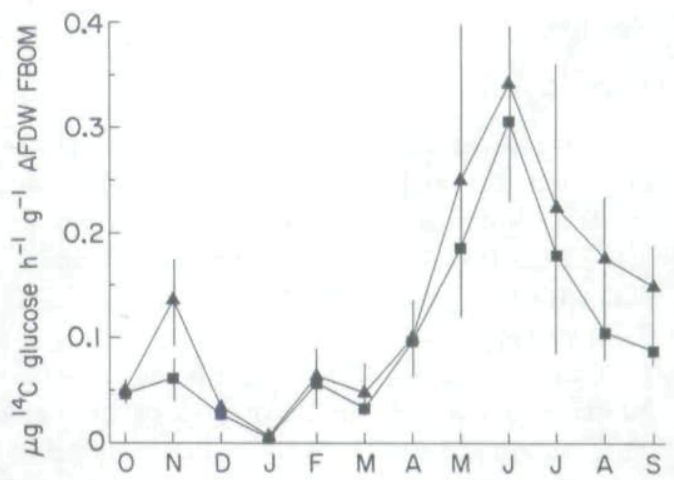

FIG. 5. Mean microbial respiration $\left(\mu \mathrm{g}{ }^{14} \mathrm{C}\right.$ glucose $\mathrm{g}^{-1}$ AFDM) of fine particulate organic matter in the pine (๘) and hardwood ( $\mathbf{\Lambda}$ ) streams. Horizontal bars indicate standard error.

Discharge was not significantly different based on aspect ( $t$-test, $P>0.05)$.

\section{Biological parameters}

No significant difference in annual mean CPOM biomass was found between streams draining pine and hardwood catchments ( $t$-test, $P>0.05$; Fig. 6). CPOM biomass in both stream types was approximately $125 \mathrm{~g}$ AFDM m $\mathrm{m}^{-2}$ in October. CPOM in the hardwood catchments increased to about $400 \mathrm{~g} \mathrm{AFDM} \mathrm{m}^{-2}$ in November, fell to about $200 \mathrm{~g} \mathrm{AFDM} \mathrm{m}^{-2}$ in December and remained there until April when there was a further fall to less than $50 \mathrm{~g}$ AFDM

TABLE 2. Stream responses in adjacent pine $(\mathrm{P})$ and hardwood $(\mathrm{H})$ catchments to storms that occurred less than 3 days prior to days of phosphorus uptake experiments*

\begin{tabular}{|c|c|c|c|c|c|c|}
\hline \multirow[b]{2}{*}{ Month } & \multicolumn{2}{|c|}{$\begin{array}{l}\text { Elevated flow } \\
(\mathrm{h}: \mathrm{min})\end{array}$} & \multicolumn{2}{|c|}{ Quick/baseflow } & \multicolumn{2}{|c|}{ Peak/initial flow } \\
\hline & $\mathbf{P}$ & H & $\mathrm{P}$ & H & $\mathbf{P}$ & H \\
\hline Oct. & - & - & & & & \\
\hline Nov. & $6: 53$ & $8: 49$ & 12.0 & 6.9 & 1.5 & 1.4 \\
\hline Dec. & - & - & & & & \\
\hline Jan. & - & - & & & & \\
\hline Feb. & $24: 50$ & $27: 18$ & 2.5 & 1.8 & 0.6 & 0.3 \\
\hline Mar. & - & - & & & & \\
\hline Apr. & - & - & & & & \\
\hline May & $6: 19$ & $8: 03$ & 1.5 & 1.1 & 0.5 & 0.3 \\
\hline Jun. & - & - & & & & \\
\hline Jul. & $26: 52$ & $29: 43$ & 1.6 & 2.1 & 0.3 & 0.3 \\
\hline Aug. & - & - & & & & \\
\hline Sept. & $4: 21$ & $5: 39$ & 5.3 & 4.33 & 0.9 & 0.7 \\
\hline
\end{tabular}

* $-=$ no storms occurred during the 3 days prior to the phosphorus uptake experiments that month. 
TABLE 3. Characteristics of streams according to basin side. Streams on the north-east side of the basin (SE aspect) were steeper than streams on the south-east side (NE aspect)

\begin{tabular}{|c|c|c|c|c|c|c|}
\hline \multirow{2}{*}{$\begin{array}{l}\text { Aspect } \\
\text { Catchment }\end{array}$} & \multicolumn{3}{|c|}{ South-east } & \multicolumn{3}{|c|}{ North-west } \\
\hline & 1 & 2 & 3 & 14 & 17 & 18 \\
\hline Manning $n^{*}$ & 0.178 & 0.120 & 0.267 & 0.304 & 0.295 & 0.322 \\
\hline Mean CPOM $\left(\mathrm{g} \mathrm{m}^{-2}\right)$ & 328.8 & 228.3 & 322.8 & 207.7 & 178.9 & 133.3 \\
\hline Mean FPOM $\left(\mathrm{g} \mathrm{m}^{-2}\right)$ & 116.9 & 95.0 & 81.8 & 94.6 & 83.1 & 58.2 \\
\hline
\end{tabular}

* $n$ was calculated from the Manning equation using chloride measured velocities.

$\mathrm{m}^{-2}$. CPOM in the pine catchments increased gradually between October and February to about $200 \mathrm{~g} \mathrm{AFDM} \mathrm{m} \mathrm{m}^{-2}$, fell to about $65 \mathrm{~g}$ AFDM m ${ }^{-2}$ in March and then declined steadily to low levels in the summer. Amounts of CPOM in the pine streams dropped dramatically in March, whereas there was no marked decrease in the hardwood streams until April. The latter contained significantly more CPOM in March
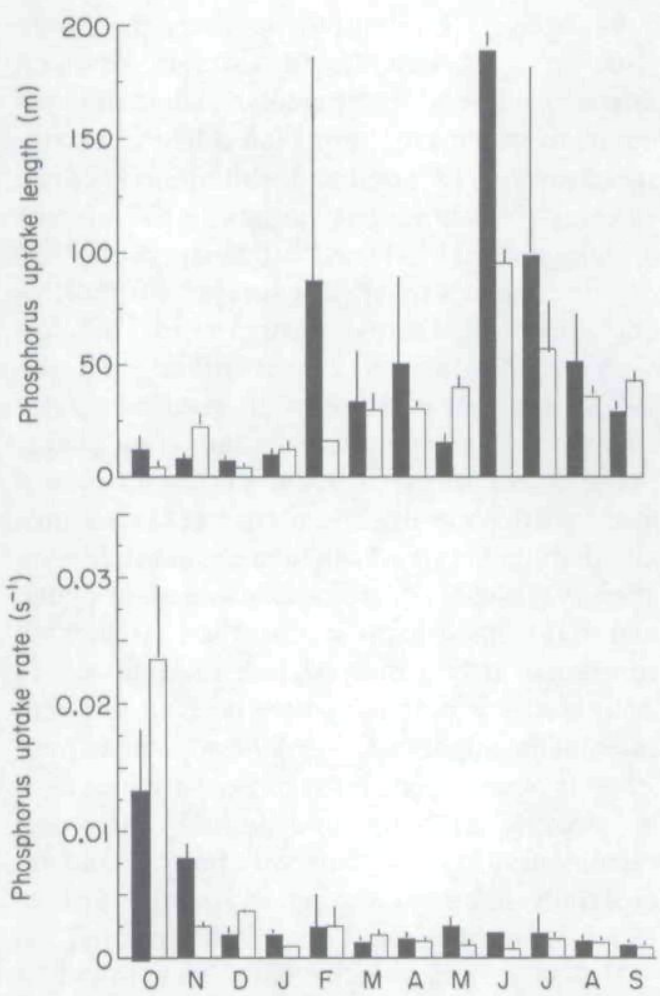

FIG. 6. (a) Mean phosphorus uptake length (m) and (b) uptake rate $\left(\mathrm{s}^{-1}\right)$ in streams draining the pine ( $\left.\mathbf{m}\right)$ and hardwood ( $\square$ ) catchments $(n=3)$. Horizontal bars indicate standard error.
(ANOVA, $P<0.05$ ). Nevertheless, mean annual CPOM biomass was the same in both catchment types. We found significantly more CPOM accumulated on the less steep (SE) side of the basin (Table 3), and it is possible that the slower current velocity of these streams resulted in more CPOM retention.

FPOM biomass was not significantly different between the pine and hardwood streams on either a monthly or annual basis (paired $t$-test, $P>0.05$; Fig. 7). FPOM biomass was highest in autumn, declined in February when discharge was high, increased somewhat in the spring when discharge was stable and then decreased in the summer when discharge again increased. For all streams combined, monthly FPOM biomass was negatively correlated with both discharge and velocity $(R=-0.606, P<0.001$, $n=48$; and $R=-0.447, P<0.0002, n=72$ ). FPOM biomass was not correlated with stream slope.

Microbial respiration of FPOM was significantly lower in pine streams than hardwood streams $(t$-test, $P<0.005)$ but the annual pattern was the same. Microbial respiration was lowest in autumn, increased slightly in February and then increased further between March and June as water temperatures increased. Respiration then declined between June and September (Fig. 8), perhaps because of a decline in FPOM quality. Despite differences in temperature between catchments on the NW and SE sides of the basin, no significant difference in microbial respiration was found between basin sides.

\section{Phosphorus retention}

Phosphorus retention was similar in pine and hardwood catchments as indicated by uptake length and uptake rate (ANOVA, $P>0.05$; 
Fig. 9). Retention appeared to be governed by changes in flow, as discharge and velocity were negatively correlated $(R=-0.658, R$ $=-0.772, P<0.05)$ with retention. Streams were most retentive of phosphorus in autumn when discharge was low, whereas large storms in February were accompanied by decreased retention. Retentiveness gradually increased during spring when there were no large storms just prior to phosphorus uptake experiments. In June and July, following several large storms, streams again became less retentive. As flow decreased in late summer and early autumn, streams gradually became more retentive.

Although annual patterns of retention were similar between catchment types, changes in both discharge and phosphorus retention were more pronounced in the pine streams than in the hardwood streams. During low-flow periods (e.g. October-January, April-May, September) pine catchments were often more retentive than hardwood catchments. During high-flow periods (e.g. February, June, July) pine catchments were typically less retentive than hardwood catchments. However, uptake length did not appear to respond proportionately to changes in discharge as discharge was only 1.5 times more variable in pine than hardwood streams, whereas uptake length was twice as variable in pine streams than in hardwood streams.

Catchment location (i.e. slope) also influenced uptake. Perhaps because velocity was faster on the steep side of the basin and less CPOM accumulated in the steeper streams, uptake length was significantly longer in steeper streams (ANOVA, $P<0.03$ ). In contrast, uptake rate, which is less dependent on velocity, was not significantly different between steep and more gradually sloping streams.

\section{Discussion}

Ecosystem relative stability (Waide, 1988) was defined by Webster, Waide \& Patten (1975) in terms of resistance to change and resilience (time required to return to preperturbation conditions). Ecosystems that are more resistant to change and more resilient after a disturbance are considered to be more stable than systems that are less resistant or resilient. Van Voris et al. (1980) conducted a microcosm study using nutrient retention as a measure of stability and illustrated that complex ecosystems were more resistant to disturbances (i.e. retained more nutrients). Minshall et al. (1983) also used retention as a measure of stability. They found that small headwater streams were more effective at retaining and reusing nutrients and organic matter than mid-sized streams because midsized streams had more variable discharge regimes, large-scale bed movements and a less constant food base. Others have related stability to accumulation (Vitousek \& Reiners, 1975) and storage of organic matter (Golley, 1974; O'Neill et al., 1975; O'Neill \& Reichle, 1980). Vitousek \& Reiners (1975) suggested that ecosystems in a growth phase that are accumulating biomass should be more retentive and therefore more stable than immature or senescent ecosystems. Golley (1974) and others (O'Neill et al., 1975; O'Neill \& Reichle, 1980) found that ecosystems with a large pool of organic matter were more stable than ecosystems with less organic matter storage.

According to the results of Van Voris et al. (1980), the pine streams used in this study should have been less retentive because they were structurally less complex than streams draining mixed hardwood catchments. Allochthonous inputs to streams draining pine catchments consisted entirely of wood and white-pine needles, whereas allochthonous inputs into streams draining mixed hardwood catchments consisted of wood and a variety of leaf types with different breakdown rates. Furthermore, because the pine catchments had been deforested in the 1950 s, it is likely that erosion reduced terrestrial soil organic matter. Bormann et al. (1974) found that deforested catchments lost nine times more particulate organic matter (POM) annually than undisturbed catchments and that even after POM losses decreased, losses of inorganic material from streams in disturbed catchments continued as a result of increased flows. A decreased soil organic matter layer in the pine catchments might explain why discharge in pine streams was significantly more variable than in streams draining undisturbed hardwood catchments (Fig. 4). This variability would be especially apparent during wet years such as 1988 , when the ground was often saturated.

Discharge and velocity have been found to be important determinants of solute and particulate retention (Meyer, 1979; Minshall et al., 1983; Minshall et al., 1985). Results from our study illustrate the importance of hydrology from two perspectives. First, canopy-related 
differences in discharge influenced retention. Because of variable discharge regimes in the pine streams, phosphorus retention was also more variable in pine streams than in hardwood streams (Fig. 9). Annual retention was not different between the two catchment types because high losses that occurred during storms in the pine-catchment streams were compensated for by the relatively high retention in these streams during low flow.

The second way hydrology affected retention was via differences in stream slopes. Streams on the NW side of the basin were steeper than streams on the SE side of the basin, had higher velocities (ANOVA, $P<0.03$ ) and lower roughness. As a result, steep streams accumulated significantly (ANOVA, $P<0.03$ ) less CPOM than less steep streams on the opposite side of the basin (SE). There were no differences in FPOM concentrations related to slope. As a result of slower velocities and a higher CPOM biomass, uptake lengths were shorter in more gradually sloping streams (SE). This relationship between stream slope and phosphorus retention indicates that geomorphology may be one of the most important factors determining phosphorus retention.

Mulholland, Steinman \& Elwood (1990) demonstrated that stable isotope uptake experiments overestimate uptake length. Based on a comparison of radiolabelled and stable phosphorus uptake in Walker Branch, Tennessee, they estimated that biological uptake of phosphorus was saturated at less than $10 \mu \mathrm{g} 1^{-1}$ SRP. Although we kept our release concentrations as low as possible, their results suggest that our limited ability to demonstrate biological differences among streams may have been a consequence of saturated biological uptake. Thus our results emphasize physical differences among streams.

Nutrient and organic matter retention are important not only because they provide information about ecosystem recovery rate but also because they are the basis of production. Whether a stream is autotrophic or heterotrophic, the ability to retain and recycle nutrients and carbon will determine productivity and trophic dynamics. Although pine streams exhibited large fluctuations in discharge and phosphorus retention, on average they were no less retentive of phosphorus and organic matter than streams draining mixed hardwood forests. Therefore, based solely on retention capabili- ties, streams draining pine catchments should be no less productive than streams draining mixed hardwood catchments. However, a lack of ecosystem complexity (i.e. uniform low quality allochthonous inputs) in pine streams may limit productivity in ways other than via retention. For example, uniformly low quality allochthonous inputs to pine streams result in the formation of FPOM that supports less microbial activity (i.e. is of lower quality) than that found in streams draining mixed hardwood catchments. Low quality FPOM may limit macroinvertebrate diversity and production in such streams (Woodall \& Wallace, 1972).

A current emphasis of stream ecosystem research is on interbiome comparisons with the objective of elucidating fundamental regional differences in nutrient-retention mechanisms. The strong impact of slope and possible implications of disturbance history on phosphorus retention demonstrate the need to choose sites for comparison carefully. Newbold et al. (1981) suggested that in streams with different geomorphologies (i.e. deeply incised streams constrained by hillslopes versus broad meandering streams), physical factors rather than biological should have the major influence on nutrient retention. If the effects of physical characteristics such as slope are not carefully examined, and long-term disturbance or land-use histories taken into account, we take the risk of attributing differences in physical or historical features to biome characteristics.

\section{Acknowledgments}

We express our appreciation to all those at the Coweeta Hydrologic Laboratory who provided assistance. Jim Deal and Kitty Reynolds were especially helpful. John Hutchens provided valuable sample collection assistance and John, Nick Zemo and Chris Marshall helped with sample processing. This work was supported by a National Science Foundation doctoral dissertation improvement grant (BSR8719571) and a grant from the NSF Long-Term Biological Studies Program (BSR8514328).

\section{References}

Bencala K.E., McKnight D.M. \& Zellweger G.W. (1987) Evaluation of natural tracers in an acidic and metal-rich stream. Water Resources Research, 23, 827-836. 
Bormann F.H., Likens G.E., Siccama T.G., Pierce R.S \& Elton J.S. (1974) The export of nutrients and recovery of stable conditions following deforestation at Hubbard Brook. Ecological Monographs, 44, 255-277.

Cromack K. Jr. \& Monk C.D. (1975) Litter production, decomposition, and nutrient cycling in a mixed hardwood catchment and a white pine catchment. Mineral Cycling in Southeastern Ecosystems (Eds F.G. Howell, J.B. Gentry and M.H. Smith), pp. 609-624. National Technical Information Service, Springfield, Virginia.

D'Angelo D.J. (1990) Mechanisms governing phosphorus retention in streams. Ph.D. Dissertation. Virginia Polytechnic Institute and State University, Blacksburg, Virginia.

Elwood J.W., Newbold J.D., O'Neill R.V., Stark R.W. \& Singley P.T. (1981) The role of microbes associated with organic and inorganic substrates in phosphorus spiralling in a woodland stream. Verhandlungen der Internationalen Vereinigung für Theoretiche und Angewandte Limnologie, 21, $850-856$.

Fisher S.G. \& Likens G.E. (1973) Energy flow in Bear Brook, New Hampshire: an integrative approach to stream ecosystem metabolism. Ecological Monographs, 43, 421-439.

Golley F.B. (1974) Structural and functional properties as they influence ecosystem stability. Proceedings of the First International Congress of Ecology, pp. 97-102. The Hague, Netherlands.

Gregory S.V. (1978) Phosphorus dynamics on organic and inorganic substrates in streams. Verhandlungen der Internationalen Vereinigung für Theoretiche und Angewandte Limnologie, 20, 1340-1346.

Helvey J.D. (1967) Interception by Eastern White Pine. Water Resources Research, 3, 723-729.

King G.M. \& Berman T (1984) Potential effects of isotopic dilution on apparent respiration in ${ }^{14} \mathrm{C}$ heterotrophy experiments. Marine Ecology, 19, 175-180.

Meyer J.L. (1979) The role of sediments and bryophytes in phosphorus dynamics in a headwater stream ecosystem. Limnology and Oceanography, 24, 365-376.

Minshall G.W., Cummins K.W., Petersen R.C., Cushing C.E., Bruns D.A., Sedell J.R. \& Vannote R.L. (1985) Developments in stream ecosystem theory. Canadian Journal of Fisheries and Aquatic Sciences, 42, 1045-1055.

Minshall G.W., Petersen R.C., Cummins K.W., Bott T.L., Sedell J.R., Cushing C.E. \& Vannote R.L. (1983) Interbiome comparison of stream ecosystem dynamics. Ecological Monographs, 53, 1-25.

Mulholland P.J., Newbold J.D., Elwood J.W., Ferren L.A. \& Webster J.R. (1985) Phosphorus spiralling in a woodland stream: seasonal variations. Ecology, 66, 1012-1023.

Mulholland P.J., Steinman A.D. \& Elwood J.W. (1990) Measurement of phosphorus uptake length in streams: comparison of radiotracer and stable $\mathrm{PO}_{4}$ releases. Canadian Journal of Fisheries and Aquatic Sciences, 47, 2351-2357.

Monk C.D., Crossley D.A., Swank W.T., Todd R.L., Waide J.B. \& Webster J.R. (1977) An overview of nutrient cycling research at Coweeta Hydrologic Laboratory. Catchment Research in Eastern North America (Ed. D.L. Correll), pp. 505-526. Smithsonian, Washington, DC.

Newbold J.D., Elwood J.W., O'Neill R.V. \& VanWinkle W. (1981) Measuring nutrient spiralling in streams. Canadian Journal of Fisheries and Aquatic Sciences, 38, 860-863.

Newbold J.D., Mulholland P.J., Elwood J.W. \& O'Neill R.V. (1982) Organic carbon spiralling in stream ecosystems. Oikos, 38, 266-272.

Newbold, J.D., Elwood J.W., O'Neill R.V. \& Sheldon A.L. (1983) Phosphorus dynamics in a woodland stream ecosystem: a study of nutrient spiralling. Ecology, 64, 1249-1265.

Odum E.P. (1969) The strategy of ecosystem development. Science, 164, 262-270.

O'Neill R.V., Harris W.F., Ausmus B.S. \& Reichle D.E. (1975) A theoretical basis for ecosystem analysis with particular reference to elemental cycling. Mineral Cycling in Southeastern Ecosystems (Eds F.G. Howell, J.B. Gentry and M.H. Smith), pp. 28-40. National Technical Information Service, Springfield, Virginia.

O'Neill R.V. \& Reichle D.E. (1980) Dimensions of ecosystem theory. Forests: Fresh Perspectives From Ecosystem Analysis (Ed. R.H. Waring), pp. 11-26. Oregon State University Press, Corvallis, Oregon.

Reynolds B.C. \& Deal J.M. (1986) Procedures for chemical analysis at the Coweeta Hydraulic Laboratory. Coweeta Hydrologic Laboratory, Otto, North Carolina.

Swank W.T. \& Crossley D.A. (1988) Introduction and site description. Forest Hydrology and Ecology at Coweeta (Eds W.T. Swank and D.A. Crossley), pp. 1-16. Springer-Verlag, New York.

Swank W.T. \& Douglass J.E. (1974) Streamflow greatly reduced by converting deciduous hardwood stands to pine. Science, 185, 857-859.

Swank W.T. \& Miner N.H. (1968) Conversion of hardwood-covered catchments to white pine reduces water yield. Water Resources Research, 4, 947-954.

Swift L.W. Jr., Cunningham G.B. \& Douglass J.E. (1988) Climatology and hydrology. Forest $\mathrm{Hy}$ drology and Ecology at Coweeta (Eds W.T. Swank and D.A. Crossley), pp. 35-56. Springer-Verlag, New York.

Triska F.J., Sedell J.R. \& Gregory S.V. (1982) Coniferous forest streams. Analysis of Coniferous Forest Ecosystems in the Western United States (Ed. R.L. Edmonds), pp. 292-332. Hutchinson Ross, Stroudsburg, Pennsylvania.

Triska F.J., Kennedy V.C., Avanzino R.J., Zellweger G.W. \& Bencala K.E. (1989) Retention and transport of nutrients in a third-order stream: channel processes. Ecology, 70, 1877-1892.

Van Voris P., O'Neill R.V., Emanuel W.R. \& Shugart H.H. Jr. (1980) Functional complexity and ecosystem stability. Ecology, 61, 1352-1360.

Vitousek P.M. \& Reiners W.A. (1975) Ecosystem succession and nutrient retention: A hypothesis. Bioscience, 25, 376-381.

Waide J.B. (1988) Forest ecosystem stability: Re- 
vision of the resistance-resilience model in relation to observable macroscopic properties of ecosystems. Forest Hydrology and Ecology at Coweeta (Eds W.T. Swank and D.A. Crossley), pp. 383406. Springer-Verlag, New York.

Webster J.R., Waide J.B. \& Patten B.C. (1975) Nutrient recycling and the stability of ecosystems. Mineral Cycling in Southeastern Ecosystems (Eds
F.B. Howell, J.B. Gentry and M.H. Smith), pp. 1-27. National Technical information Service, Springfield, Virginia.

Woodall W.R. Jr. \& Wallace J.B. (1972) The benthic fauna in four small southern Appalachian streams. American Midland Naturalist, 88, 393-407.

(Manuscript accepted 8 June 1991) 
This document is a scanned copy of a printed document. No warranty is given about the accuracy of the copy. Users should refer to the original published version of the material. 